\title{
Influence of mixing and extraction parameters on virgin olive oil quality
}

\author{
By R. Amirante ${ }^{1}$, E. Cini ${ }^{2}$, G.L. Montel ${ }^{3}$ and A. Pasqualone ${ }^{4 *}$ \\ ${ }^{1}$ Dipartimento SAVA, Università del Molise, Località Vazzieri, 76100 Campobasso, Italy. \\ amirante@foodeng.unimol.it \\ ${ }^{2}$ Dipartimento DIAF, Università di Firenze, Piazzale delle Cascine 15, 50144 Firenze, Italy. \\ ecini@diaf.agr.unifi.it \\ ${ }^{3}$ Istituto di Meccanica agraria, Università degli Studi di Bari, via Amendola, 165/A, 70126, \\ Bari, Italy. gianluca.montel@agr.uniba.it \\ ${ }^{4}$ Istituto di Industrie agrarie, Università degli Studi di Bari, via Amendola, 165/A, 70126, \\ Bari, Italy. antonella.pasqualone@agr.uniba.it
}

\section{RESUMEN}

Influencia del batido y de los parámetros de extracción en la calidad del aceite de oliva virgen.

El tiempo de batido, la temperatura y el grado de dilución de la pasta de aceituna, son los principales parámetros que pueden sufrir cambios durante el batido y la extracción del aceite. Estos pueden diferir mucho de un proceso a otro, habiendo sido observadas variaciones en los aceites de molino de Toscana, entre $26^{\circ} \mathrm{C}$ y $36^{\circ} \mathrm{C}, 40^{\prime}$ y 90 ', y $10 \%$ y $50 \%$ respectivamente, para la temperatura, el tiempo de batido y el agua añadida durante la extracción por centrifugación.

Este artículo presenta los resultados de algunos ensayos experimentales realizados durante el año 1998 con aceite de oliva de Toscana. El tiempo de batido y la temperatura, así como la dilución de la pasta de aceitunas, se variaron uno a uno y se evaluaron por su influencia en el rendimiento de la extracción y la calidad del aceite. Las mejores condiciones para optimizar el rendimiento y la calidad del producto fueron identificadas.

PALABRAS-CLAVE: Aceite de oliva virgen - Calidad - Dilución de la pasta - Rendimiento - Temperatura - Tiempo de batido.

\section{SUMMARY}

Influence of mixing and extraction parameters on virgin olive oil quality.

The mixing time, the temperature and the degree of dilution of olive paste are the main parameters liable to change during mixing and oil extraction. They can greatly differ from a processing run to another, with variations being observed in Tuscan oil mills, between $26^{\circ} \mathrm{C}$ and $36^{\circ} \mathrm{C}, 40^{\prime}$ and $90^{\prime}$, and $10 \%$ and $50 \%$ respectively, for the temperature, the mixing time and the water added during the centrifugal extraction.

This note reports on the results of some experimental trials run during the 1998 olive oil year in Tuscany. The mixing time and temperature as well as the olive paste dilution were changed one at a time and were assessed for their influence on extraction yield and oil quality. The best conditions to optimise the product yield and quality were identified.

KEY-WORDS: Dilution of olive paste - Mixing time - Quality Temperature - Virgin olive oil - Yield.

\section{INTRODUCTION}

Food quality depends on all its chemico-physical, nutritional and organoleptic properties. In particular, for olive oil, as for all vegetable products, quality originates from the choice of cultivars and the related cultural practices, as well as the from the harvest time (Ranalli et al., 1998). The choice of harvest techniques, post-harvest operations and oil extraction technologies is equally important (Montedoro and Servili, 1992). After all, olive oil quality necessitates the observance and safeguard of the original product intrinsic properties, even enhanced by a good extraction process (Amirante P., 1995).

Oil is dispersed in very minute drops in the cells of olive pulp. After the crushing, which is aimed at breaking the fruit in fragments, the subsequent mixing of the obtained paste breaks the still entire oil cells and causes the oil drops dispersed in vegetable water to aggregate.

The mixing time and temperature, as well as the degree of dilution of olive paste, are the main parameters liable to change in mixing and centrifugal extraction. They differ from a processing run to another, with variations ranging, in Tuscan oil mills, between 26 and $36^{\circ} \mathrm{C}, 40$ and $90^{\prime}$ and 10 and $50 \%$, respectively for the mixing temperature, the mixing time and the water added during the centrifugal extraction, as ascertained directly by the Authors through oil mills inspections.

The aim of this work was to better define the influence of these parameters on olive oil quality properties and on extraction yields. For this purpose, during the 1998 oil year, experimental trials were run in a Tuscan oil mill changing the mixing temperature, the mixing time, and the dilution of the mixed paste one by one. The assessment of the quality of extracted oil and the yields associated with each variation enabled to identify the best conditions to obtain - with good yields - an optimal quality product.

\section{EXPERIMENTAL}

\subsection{Materials}

The olives were hand picked in the middle of the olive-oil year of 1998 (from 17 to 27 November) and 
were pooled to oil mills in small uniform lots, of $450-500 \mathrm{~kg}$ each, represented by a mixture of the most common cultivars in Tuscany (notably $10 \%$ of Moraiolo, $45 \%$ of Leccino and $45 \%$ of Frantoio). The olives were stored in plastic bins and processed in the 24 hours after being pooled. Five samplings for each parameter combination considered were done.

\subsection{Mixing and centrifugal extraction conditions}

Experimental trials were run at an industrial level using a plant equipped with a disk crusher (Alfa laval), a mixer mod. 700 (Alfa Laval), a short cone and variable dynamic pressure decanter (VDP-decanter) mod. UVNX-X20 (Alfa Laval) and a vertical centrifuge (Alfa Laval). This decanter, as described in (Amirante R. et al., 1999), is able to separate immediately the pomace, making the cylindrical part available for a more complete separation of minute solid particles and of the two liquid phases from each other. Moreover, the presence of a barrier, coupled with a very inclined cone, submits the pomace to an additional dynamic pressure allowing more oil to be recovered. Lastly, this decanter enables working with less diluted pastes and at lower temperatures. In the trials, the following process parameters were changed one by one: mixing temperature in the $27-35^{\circ} \mathrm{C}$ range $(27$, $32,35^{\circ} \mathrm{C}$ ); mixing time in the $30-60$ minutes interval $(30,45,60 \mathrm{~min})$; dilution of the paste entering the decanter in the $19-41 \%$ range $(19,32,41 \%)$. The rate of oil paste $\left(22^{*} 10^{2} \mathrm{~kg} / \mathrm{h}\right)$ and the differential speed between the screw and the drum $(\Delta n=11$ rpm) were kept unchanged.

\subsection{Analytical methods}

At each variation in time, temperature and olive paste dilution, the yield was calculated and a $250 \mathrm{~g}$ oil sample was taken and kept in a dark glass bottle at $4^{\circ} \mathrm{C}$ till the carrying out of the determinations for: percent acidity, peroxide number, $\mathrm{k}_{232}$ and $\mathrm{k}_{270}$, Kreiss reaction, following the methods prescribed by the legislation in force (EEC Commission Regulation $n$. 2568/91). The resistance to thermal oxidation was also determined by measuring the induction time by means of a Rancimat apparatus mod. 679 (Metrohm Italiana) at $120^{\circ} \mathrm{C}$, with an air flow rate of $20 \mathrm{l} / \mathrm{h}$ and a conductivity of $200 \mu \mathrm{S} / \mathrm{cm}$. The chlorophyll content was also determined by the method reported by Wolff (1968); the total content of phenolic compounds, expressed as gallic acid, was measured by extraction and purification according to the method by Cortesi et al. (1981) and by the subsequent colorimetric quantification (Favati et al., 1994).

\section{RESULTS AND DISCUSSION}

Considering that all the oils being analysed were characterised by a good quality and showed the analytical indices, prescribed by the legislation in force, within the limits fixed for the category of extra virgin oils, this note illustrates the results concerning other quality-related parameters that showed marked variations and were particularly interesting, as well as the results concerning extraction yields. In particular, the following were considered: the chlorophyll content, a parameter which is important for typically green-coloured Tuscan oils, the phenolic compound content, correlated both to the sensory properties of oils and to their resistance to oxidation (Tsimidou, 1998; Romani et al., 1999) and the resistance to thermal oxidation, assessed by Rancimat method.

The influence of olive paste dilution on oil quality and extraction yields was shown to be high. The changes in the phenolic compound content of extracted oils, in their resistance to oxidation and in the chlorophyll content as a function of dilution, are plotted versus the change in time and mixing temperature in Figures 1-3, respectively. Figure 4 shows the variation in extraction yield versus the same parameters. In particular, the optimal dilution values, considering that the olives of this test were characterised by a very low ageing degree and a humidity value comprised from 43 to $45 \%$, ranged between 19 and $32 \%$, at temperatures of 32 and $27^{\circ} \mathrm{C}$, respectively. These operational conditions enabled obtaining oils with a good phenolic compound content (253 ppm gallic acid, on average) (Figure 1) and a high resistance to oxidation (14.9 h, on average) (Figure 2). Anyway, the best results, in terms of extraction yield, were obtained only with $32 \%$ water added to olive paste, with average yields of $15.8 \mathrm{~kg}$ oil $/ 100 \mathrm{~kg}$ olives, as compared with a $13.5 \%$ yield obtained, on average, with $19 \%$ dilution (Figure 4). Higher dilutions, equalling $41 \%$, typical of traditional centrifugal plants, showed to have a

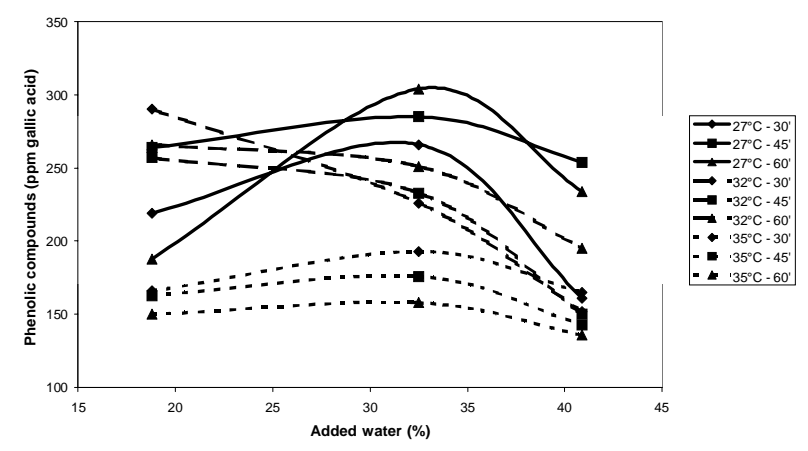

Figure 1

Changes in phenolic compound content versus olive paste dilution. 


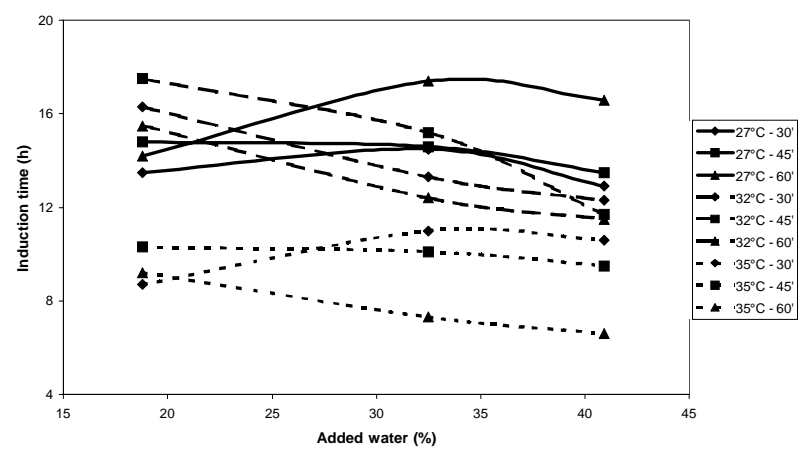

Figure 2

Changes in resistance to oxidation versus olive paste dilution.

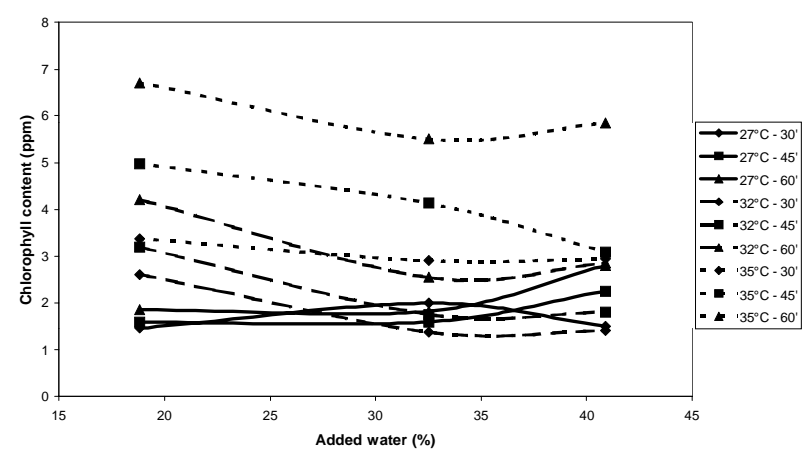

Figure 3

Changes in chlorophyll content versus olive paste dilution.

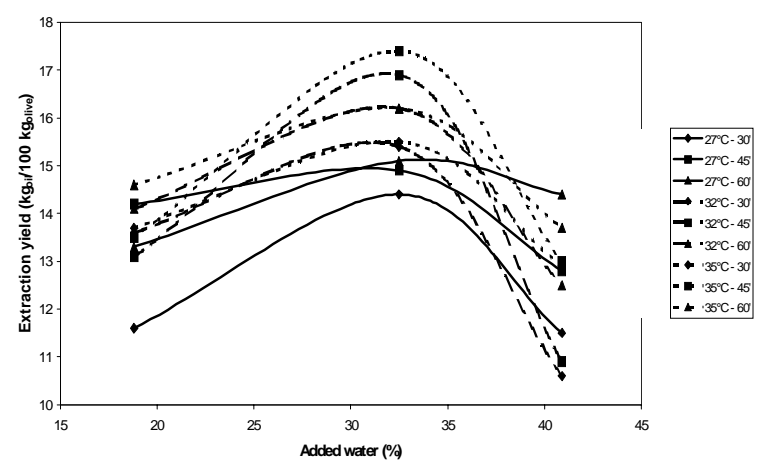

Figure 4

Changes in extraction yield versus olive paste dilution.

harmful effect both on extraction yields, which decreased to $12.5 \mathrm{~kg}$ oil/100 $\mathrm{kg}$ olives, on average (Figure 4), and on oil quality, in terms of phenolic compound content (177 ppm gallic acid, on average) (Figure 1) and resistance to oxidation $(11.7 \mathrm{~h}$, on average) (Figure 2). A lower effect of dilution was observed, instead, on chlorophyll content (Figure 3).
The change in the mixing temperature greatly affected all the quality-related analytical indices considered, as well as the extraction yields. The effect of temperature on the phenolic compound content and on the resistance to oxidation of the oil obtained varied with the change in the olive paste degree of dilution. The total content of phenolic compounds in oils (Figure 1) and, subsequently, the induction time (Figure 2), decreased as temperature increased if $32 \%$ water was added, whereas they increased at temperatures shifting from 27 to $32^{\circ} \mathrm{C}$, and then decreased again, at temperatures from 32 to $35^{\circ} \mathrm{C}$, if $19 \%$ water was added. Therefore, at low dilutions $-19 \%$ water added to olive paste- temperature values close to $32^{\circ} \mathrm{C}$ enabled a more efficient extraction of phenolic compounds; at medium-high dilutions (32-41\%), higher amounts of phenolic compounds were extractable at $27^{\circ} \mathrm{C}$ (Figure 1). A similar trend was then observed for the resistance to oxidation (Figure 2). At $35^{\circ} \mathrm{C}$ and at any dilution and time values considered, both the phenolic compound content and induction time were lower (with mean values of $159 \mathrm{ppm}$ gallic acid and $9.2 \mathrm{~h}$, respectively) as compared to those obtainable by mixing both at $27^{\circ} \mathrm{C}$ (242 ppm gallic acid and $14.6 \mathrm{~h}$, on average) and $32^{\circ} \mathrm{C}$ (223 ppm gallic acid and $13.9 \mathrm{~h}$, on average). On the other hand, both the chlorophyll content (Figure 3 ) and the extraction yield (Figure 4) increased rising the mixing temperature.

As far as the mixing time is concerned, the effect of its variation on the total phenolic compound content (Figure 1) and on the resistance to thermo-oxidation (Figure 2) was not so evident, since the effect of temperature and olive paste dilution prevailed. On the contrary, both the chlorophyll content (Figure 3 ) and the extraction yield (Figure 4) increased as the mixing time was extended. In particular, the yield increased from $13.2 \%$ to $14.1 \%$, on average, by extending the mixing time from 30 ' to $45^{\prime}$, whereas increasing time from $45^{\prime}$ to 60 ' much lower increments were achieved (mean yield of $14.4 \%$ ), also considering the waste of energy, without a corresponding improvement in quality. It is worth noting that at $35^{\circ} \mathrm{C}$, an increasing of mixing time from 45 to 60 ' caused a decrease of extraction yield from 17.4 to $16.2 \mathrm{~kg}$ oil $/ 100 \mathrm{~kg}$ olives.

Finally, as far as the overall values of residual oil contents in both pomace and vegetable water, they were found to be comprised between $2-3 \%$ and $0.3-0.5 \%$, respectively. The oil content in the olives ranged between 17.6 and $18.8 \%$.

Table I shows the quali-quantitative features of the oils corresponding to the three processing conditions, designated as $A, B$ and $C$, which resulted in the highest total phenolic compound content $(A)$ and the highest extraction yields $(B, C)$, as well as their processing parameters. All the three operating conditions being considered showed the same olive paste dilution value, that is $32 \%$, which turned to be 

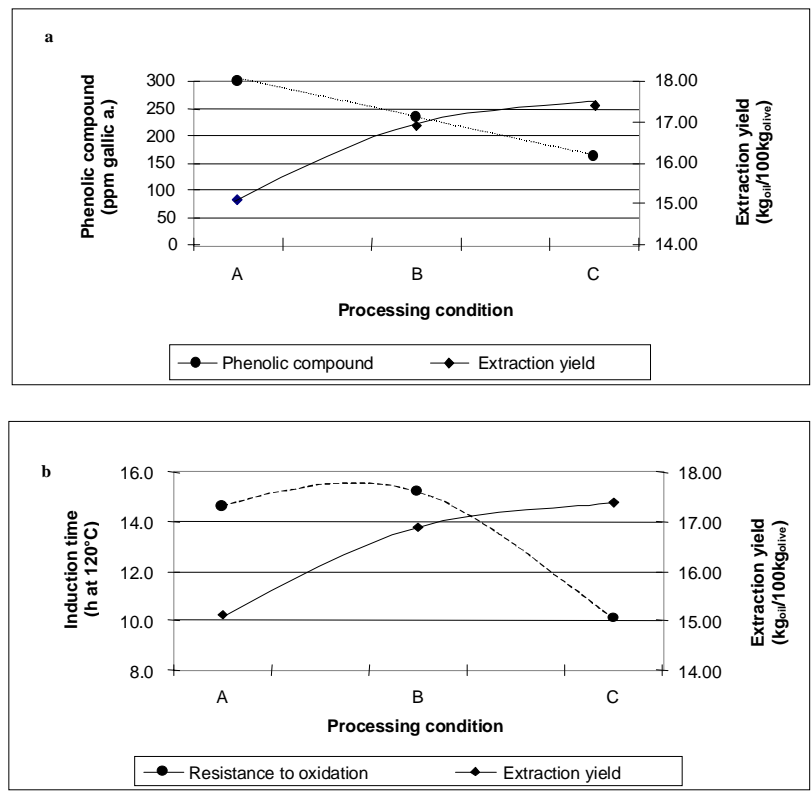

Figure 5

Changes in qualitative features and extraction yields induced by different processing conditions.

Table I

Quali-quantitative features of the oils obtained under different processing conditions

\begin{tabular}{|c|c|c|c|c|c|c|}
\hline \multicolumn{3}{|c|}{ Operating conditions } & \multicolumn{3}{|c|}{ Quality analytical characteristics } & \multirow{2}{*}{$\begin{array}{c}\text { Yield } \\
(\mathrm{kggal} / 100 \\
\mathrm{kg} \text { odive })\end{array}$} \\
\hline & $\begin{array}{c}\text { Temperature } \\
\left({ }^{\circ} \mathrm{C}\right)\end{array}$ & $\underset{(\min )}{\text { Mixing time }}$ & $\begin{array}{l}\text { Paste } \\
\text { diluition } \\
(\%)\end{array}$ & $\begin{array}{l}\text { Phenolic } \\
\text { compounds } \\
\text { (ppm gallic a.) }\end{array}$ & $\begin{array}{l}\text { Induction } \\
\text { time } \\
\text { at } 120^{\circ} \mathrm{C}(\mathrm{h})\end{array}$ & \\
\hline A & 27 & 60 & 32 & 304 & 17.4 & 15.1 \\
\hline B & 32 & 45 & 32 & 233 & 15.2 & 16.9 \\
\hline C & 35 & 45 & 32 & 176 & 10.1 & 17.4 \\
\hline
\end{tabular}

optimal to obtain a high extraction yield. The joint analysis of the extraction yields and the extracted oil quality -in terms of content of phenolic compounds (Figure 5a) and resistance to oxidation (Figure 5b)points out that the processing condition $A\left(27^{\circ} \mathrm{C}, 60^{\prime}\right)$ allowed the best quality features to be obtained but affected negatively the extraction yield that was, however, acceptable. Condition $\mathrm{C}\left(35^{\circ} \mathrm{C}, 45^{\prime}\right)$ showed the highest extraction yield and the lower values of phenolic compound content and induction time. Condition B $\left(32^{\circ} \mathrm{C}, 45^{\prime}\right)$, although enabling an extraction yield slightly lower than $\mathrm{C}$ condition, improved the quality features resulting in values close to those obtainable from the processing condition $\mathrm{A}$.

\section{CONCLUSIONS}

Based on all the results achieved, it may be stated that the setting of both times and temperatures of mixing, as well as of olive paste dilution degree, greatly affects both oil quality and extraction yields. In particular, under some of the most extreme conditions involving, for instance, $19 \%$ and/or $41 \%$ water additions to the olive paste, the extraction yields decreased, on average, by about $2 \mathrm{~kg} / 100 \mathrm{~kg}$ of processed olives, as compared to the yields obtainable with $32 \%$ dilutions. Moreover, mixing at $35^{\circ} \mathrm{C}$, the phenolic compound content and resistance to oxidation decreased by about $30 \%$, on average, as compared with mixings performed at $27^{\circ} \mathrm{C}$. Although remaining within intermediate processing conditions, it was possible to appropriately adjust the mixing parameters and subsequent dilution of olive paste, and further increase the quality of extracted oils -already high-without jeopardising yields.

\section{ACKNOWLEDGEMENTS}

Research funded by the ARSIA of Tuscany Region/Tuscan Olive-grower Association (OTA); research project "Influence of extraction techniques on oil quality.

\section{REFERENCES}

Amirante, P. (1995). Qualità, produttività e ambiente: aspetti inscindibili della nuova tecnologia olearia. Proc. of Congress «ll vino e l'olio: la meccanizzazione, l'imprenditorialità ed il mercato", Trapani (Italy), 20-23 June, in Riv. Ing. Agr. 17, 237-250.

Amirante, R., Baccioni, L., Catalano, P. y Montel, G.L. (1999). Nuove tecnologie per l'estrazione dell'olio di oliva: il decanter con cono a pressione dinamica variabile e controllo della velocità differenziale tamburo-coclea. Riv. It. Sost. Grasse, 76, 129-140.

Cortesi, N., Ponziani, A. y Fedeli, E. (1981). Caratterizzazione degli oli vergini e raffinati mediante HPLC dei componenti polari. Nota preliminare. Riv. It. Sost. Grasse, 58, 108-114.

Favati, F., Caporale, G. y Bertuccioli, M. (1994). Rapid determination of phenol content in extra virgin olive oil. Grasas y Aceites, 45 (1-2), 68-70.

Montedoro, G. F. y Servili, M. (1992). I caratteri che definiscono la qualità dell'olio di oliva. In: Qualità dell'olio di oliva e tecnologie di lavorazione. By Catalano, M., Amirante, P., Bruno, C. Conte Ed., Lecce, (Italy), 17-30.

Ranalli, A., Tombesi, A., Ferrante, M.L. y DeMattia, G. (1998). Respiratory rate of olive drupes during their ripening cycle and quality of oil extracted. J. Sci. Food Agr., 77 (3), 359-367.

Romani, A., Mulinacci, N., Pinelli, P., Vincieri, F.F. y Cimato, A. (1999). Polyphenolic content in five Tuscany cultivars of Olea Europaea L. J. Agric. Food Chem. 47, 964-967.

Tsimidou, M. (1998). Polyphenols and quality of virgin olive oil in retrospect. Italian J. of Food Sci. 10 (2), 99-116.

Wolff, J. P. (1968). Manuel d'analyse des corps gras. Azoulay Ed., Paris, (France), 197-199. 